\title{
Phytoplankton and hydrography of the Kennebec estuary, Maine, USA
}

\author{
Ming Wah Wong, David W. Townsend* \\ School of Marine Sciences, 5741 Libby Hall, University of Maine, Orono, Maine 04469-5741, USA
}

\begin{abstract}
The biomass, abundance and species composition of phytoplankton in the Kennebec estuary, Maine, USA, were investigated in relation to hydrography and light regime during 7 seasonal survey cruises. The salinity distribution ranged from 32 at the mouth to between 0 and 5 at the head, depending on the magnitude of freshwater discharge at the time of each survey. Maximum vertical salinity and temperature gradients were observed at the mouth, while local tidal mixing, combined with the freshwater flow, produced a well-mixed water column at the head of the estuary. The middle portion of the estuary was stratified on flooding and ebbing tides, but was vertically well mixed at high and low tides. Phytoplankton biomass was lowest in winter (chlorophyll $a \approx 1 \mu \mathrm{g} \mathrm{l}^{-1}$ ) and highest in summer (up to $10 \mathrm{\mu g} \mathrm{l}^{-1}$ ). The phytoplankton species assemblages at the seaward and the riverine ends of the estuary were made up of taxa with corresponding salinity preferences. Both cell numbers and biomass (chlorophyll a) exhibited a bimodal distribution along the length of the estuary in the warmer months, with the middle portions of the estuary having depressed phytoplankton standing stocks compared with the seaward and landward ends. This bimodal distribution was related to light limitation and nutrient regeneration in the middle portion of the estuary and to the production of and advective contributions of phytoplankton from both the freshwater and seaward ends.
\end{abstract}

KEY WORDS: Kennebec estuary · Maine $\cdot$ Phytoplankton - Light $\cdot$ Chlorophyll $\cdot$ Hydrography

\section{INTRODUCTION}

The Kennebec River estuary of Maine, USA, is a drowned river valley that extends approximately $35 \mathrm{~km}$ from its mouth to Merrymeeting Bay where the Androscoggin and Kennebec Rivers converge to form the Kennebec estuary (Fig. 1). Combined discharges from the Androscoggin and Kennebec Rivers range from about $150 \mathrm{~m}^{3} \mathrm{~s}^{-1}$ in late summer to $>600 \mathrm{~m}^{3} \mathrm{~s}^{-1}$ during the period of peak spring runoff. The estuary experiences relatively large tides, characteristic of the Gulf of Maine, and is one of the most important estuaries in the Gulf of Maine region in terms of the volume of freshwater discharged (Apollonio 1979). To date there have been no studies of the oceanographic characteristics of the Kennebec estuary, except that

\footnotetext{
- Addressee for correspondence.

E-mail: davidt@maine.edu
}

detailed in a technical report covering a few hydrographic stations taken by Francis et al. in 1953. Thus, prior to the work reported here there was little known about the hydrography, light regime, or phytoplankton dynamics in the Kennebec estuary despite its apparent ecological importance to the region. The purpose of the work reported here was to begin to assess the relationships among the biomass and species composition of dominant phytoplankton and various physical and environmental factors during each season. These factors included primarily the hydrography and the light regime as each varied with season and degree of freshwater discharge. The study was part of a larger program designed to compare the significance of varying levels of freshwater discharge and the resulting patterns of circulation, particle dynamics, and biological and geochemical processes in the Kennebec estuary and 2 neighboring estuaries, the Sheepscot and the Damariscotta (Laursen et al. 1996, Mayer et al. 1996, Schoudel 1996). 
Fig. 1. Map of the Kennebec estuary in relation to the Gulf of Maine

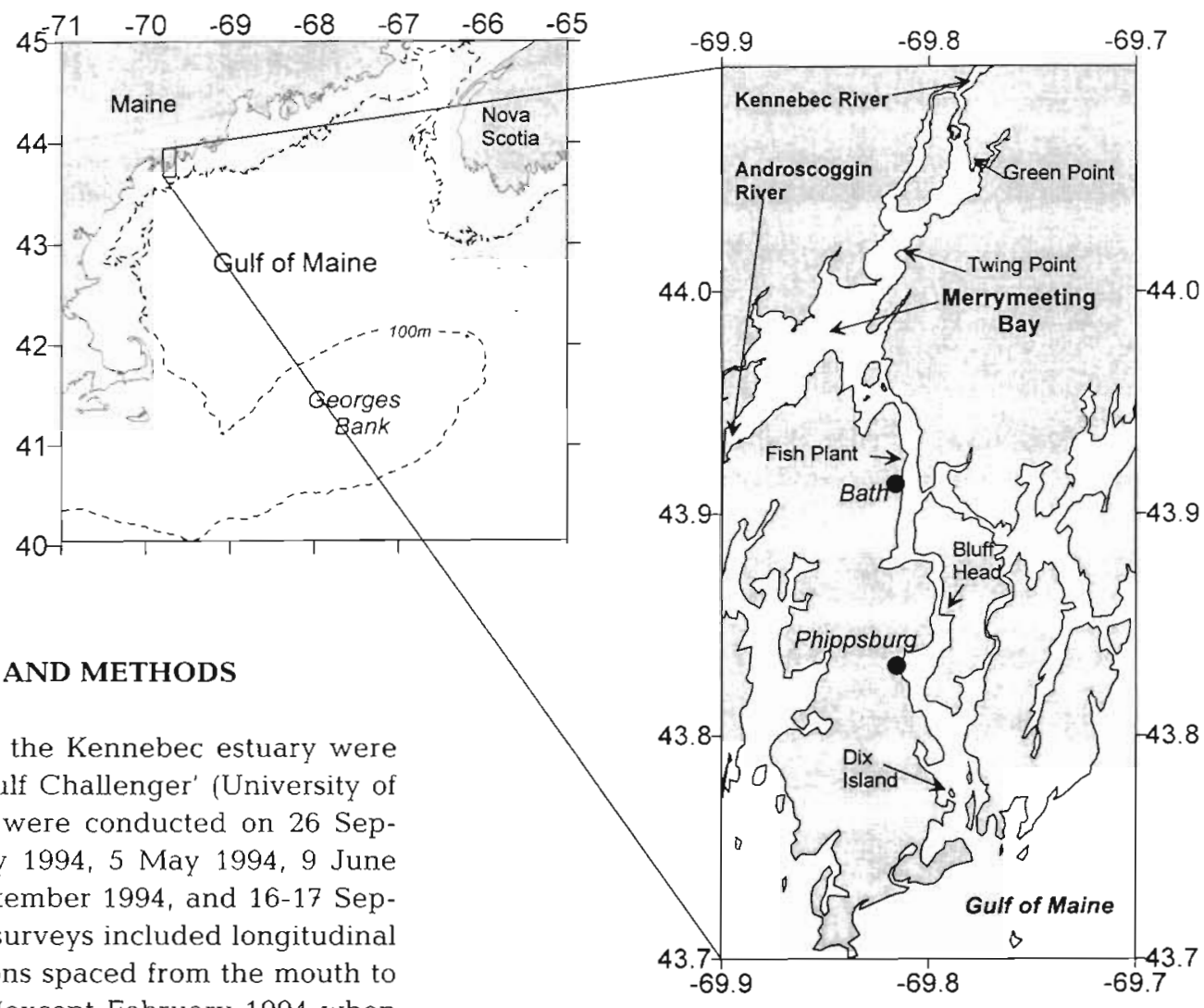

$4 \pi$, spherical LiCor underwater quantum sensor (LI193SA) corrected for variations in incident solar radiation with a matched cosine quantum sensor (LI-190SA) mounted on the deck of the ship. The PAR data were used to determine the diffuse attenuation, or extinction, coefficient $(k)$ using Beer's Law, e.g

$$
I_{z}=I_{0} \mathrm{e}^{-k z}
$$

where $I_{z}$ and $I_{0}$ are irradiance values received at 2 consecutive depths and $z$ is the change in depth in meters.

On all cruises, subsamples were taken from the Niskin bottles for phytoplankton studies and biogeochemical analyses following pre-screening through $200 \mu \mathrm{m}$ mesh netting. Chlorophyll a (chl a) and phaeopigments were determined fluorometrically (Parsons et al. 1984). Phytoplankton cell counts were made only for surface water samples (ca $1 \mathrm{~m}$ depth). The samples were preserved with acidified Lugol's solution (Parson et al. 1984) and concentrated for counting in the laboratory as follows: A $100 \mathrm{ml}$ sample was allowed to settle in a graduated cylinder for 48 to $72 \mathrm{~h}$. It was then concentrated by drawing off from the top a volume of from 50 to $90 \mathrm{ml}$ (thus giving a concentration factor of 2 to 10 for the remaining sample). This settling procedure thus allowed mostly larger species of phytoplankton (microplankton, ca 20 to $200 \mu \mathrm{m}$ ) to be retained for identification. A $1 \mathrm{ml}$ subsample was then injected into a Sedgwick-Rafter counting cell and enumerated under 100 to
Vertical profiles of photosynthetically active radiation (PAR) in the water column were measured using a 
$200 \times$ magnification with a compound microscope. The entire contents of the counting cell were enumerated, resulting in 500 to 3000 cells identified to species (when possible) for each sample. In addition to this procedure, samples from the September 1995 cruise were prepared for epifluorescence microscopy with the dual DAPI/proflavine staining method as described by Sieracki et al. (1993). $100 \mathrm{ml}$ of sample was fixed by adding $0.6 \mathrm{ml}$ of $50 \%$ stock glutaraldehyde, yielding a $0.3 \%$ final concentration. Samples were then placed in a refrigerator for $48 \mathrm{~h}$ and processed in the laboratory following the cruise. Subsamples of 5 to $20 \mathrm{ml}$ were gently filtered onto black, $25 \mathrm{~mm}$ diameter, $0.8 \mathrm{\mu m}$ pore size Nuclepore filters (Costar). The filters were then flooded with $100 \mu \mathrm{l}$ DAPI $\left(250 \mu \mathrm{g} \mathrm{m}^{-1}\right.$ of 4,6 -diamidino-2-phenylindole, Sigma Chemical Co.j and $4 \mathrm{~min}$ later $100 \mu \mathrm{l}$ proflavine $\left(250 \mathrm{\mu g} \mathrm{ml}^{-1}\right.$ of 3,6-diaminoacridine as hemisulfate salt, Sigma Chemical Co.j was added and filtered. Filters were mounted on microscope slides with a drop of immersion oil and a cover slip placed on top. The slides were stored in the dark at $-18^{\circ} \mathrm{C}$ and were examined 5 mo later using a Nikon Episcopic-Fluorescence microscope with attachment EFD-3 and filter sets $\mathrm{B}-2 \mathrm{~A}$ (for chlorophyll; excitation filter at 450 to $490 \mathrm{~nm}$, dichroic mirror at $505 \mathrm{~nm}$ and barrier filter at $520 \mathrm{~nm}$ ) and UV-2E/C (for DAPI; excitation filter at 340 to $380 \mathrm{~nm}$, dichroic mirror at $400 \mathrm{~nm}$ and barrier filter at 435 to $485 \mathrm{~nm}$ ). Despite the long storage period, the fluorescence signals remained bright enough for identification.

The concentrations of nutrients, e.g. nitrate $\left(\mathrm{NO}_{3}\right)$, nitrite $\left(\mathrm{NO}_{2}\right)$, ammonium $\left(\mathrm{NH}_{4}\right)$, silicate $\left(\mathrm{SiO}_{4}\right)$, phosphate $\left(\mathrm{PO}_{4}\right)$ and particulate phosphate $(\mathrm{PP})$, were analyzed by $T$. Loder and A. Shoudel at the University of New Hampshire, and are reported in Schoudel (1996) and Mayer et al. (1996). Particulate organic carbon (POC), particulate organic nitrogen (PON), and suspended particulate matter (SPM) were analyzed by $L$. Mayer and A. Laursen at the University of Maine (Laursen et al. 1996, Mayer et al. 1996). Total suspended particulate material (SPM) measurements were made according to the methods in Strickland \& Parsons (1972).
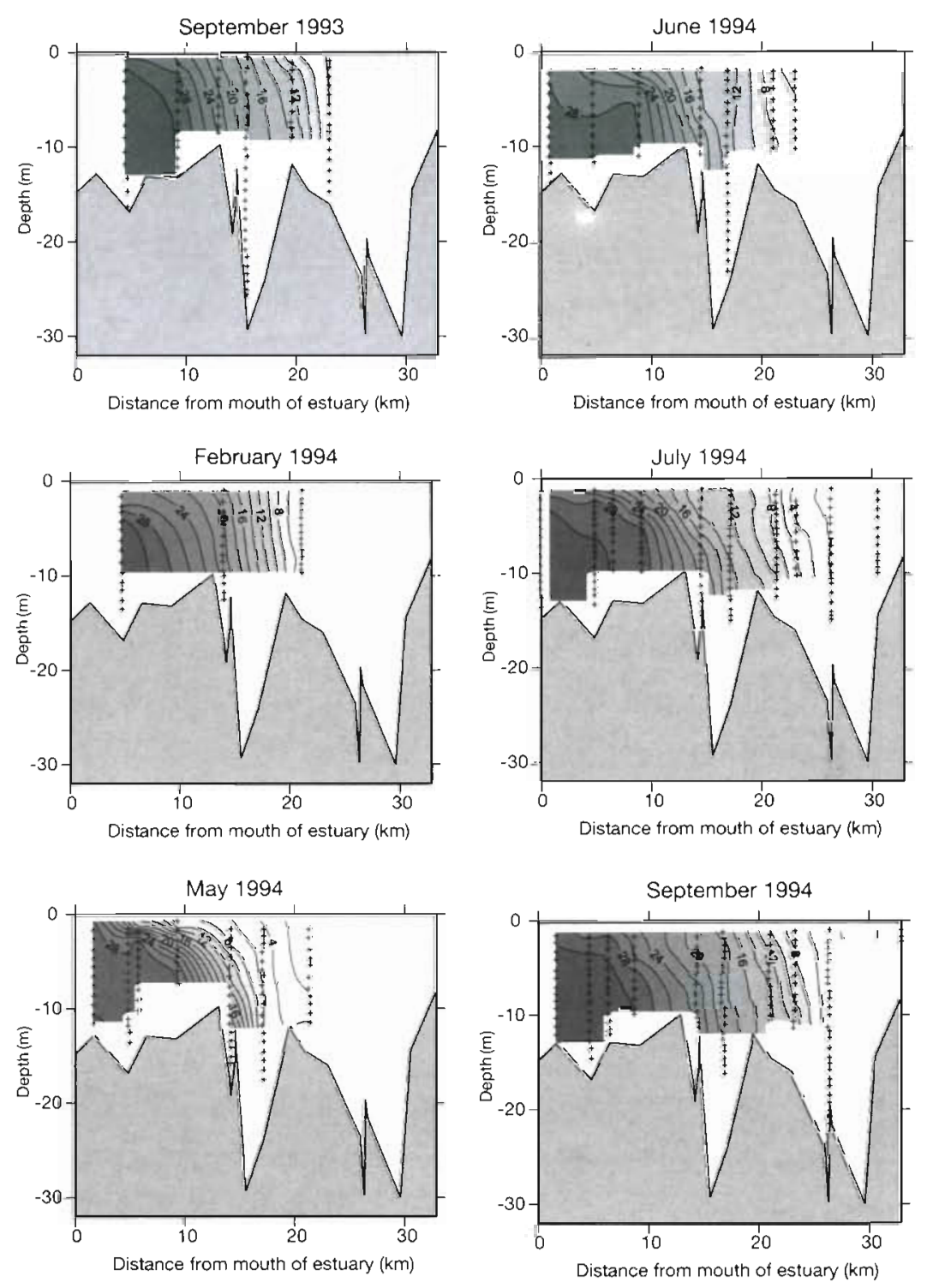

Fig. 2. Vertical section contour plots of salinity along the length of the Kennebec estuary for each of 6 survey cruises, presented as depth versus distance in $\mathrm{km}$ from the mouth of the estuary. $(+1$ Locations of the stations and sample depths

\section{RESULTS}

Hydrography

Water temperatures changed progressively from the mouth to the head of the estuary; in summer the sea water was colder and river water was warmer while in winter the opposite was true. The maximum difference between surface and bottom water temperature was found in July at the lower estuary, with the colder bottom water $\left(\sim 9^{\circ} \mathrm{C}\right)$ entering the estuary as coastal water. The deep water layer was significantly warmer in September 1993 and September $1994\left(\sim 12^{\circ} \mathrm{C}\right)$ than other 

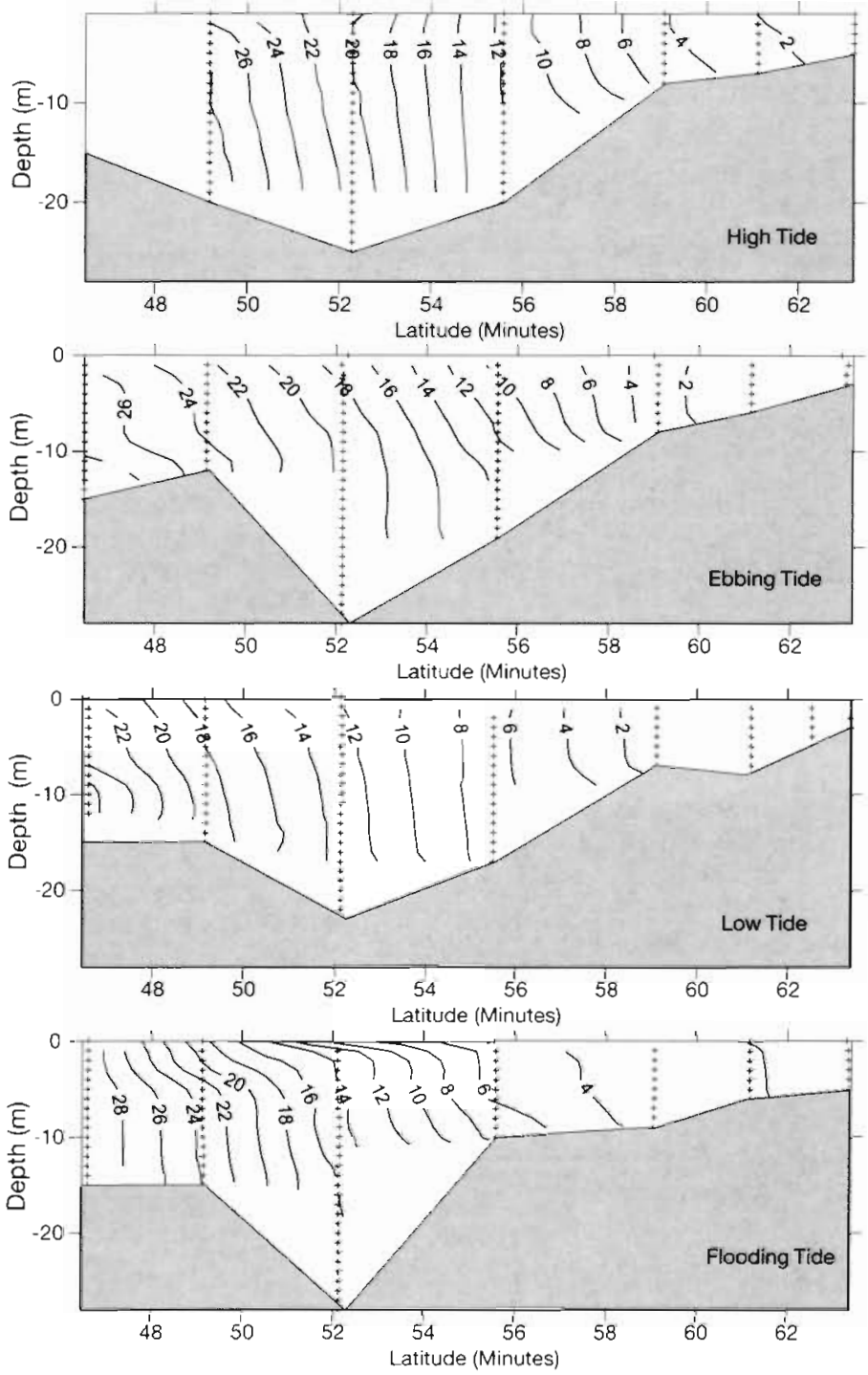

Fig. 3. Vertical section contour plots of salinity along the length of the Kennebec estuary for each of the tidal stages in the 16-17 September 1995 survey, presented as depth versus distance from the mouth of the estuary. Distance is given as minutes of latitude north of $43^{\circ} \mathrm{N}$. (+) Locations of the stations and sample depths

months. However, the temperature at the upper estuary was the warmest in July.

The density structure was controlled by salinity, with contour plots of sigma-t matching almost exactly those of salinity; for this reason plots of salinity only are presented here. Vertical sections of salinity (Figs. 2 \& 3) indicate that the Kennebec can be classified as a partially mixed estuary: salinity changed gradually from the surface to the bottom with the fresher water flowing in from the river on the surface and diluting the saltier seawater invading from the bottom. In the upper estuary, the water column was well mixed by tidal mixing as well as by the force of the relatively large vol- ume of freshwater being discharged. The lower salinity riverine water flowing in at the surface and saltier water entering the estuary at the bottom resulted in maximum vertical stratification in the middle and lower estuary 10 to $15 \mathrm{~km}$ from the mouth). The positions of specific isohalines differed among seasons (Figs. 2 \& 3). In May 1994, isohalines were pushed down the estuary and showed the greatest horizontal gradient at the lower estuary, reflecting the increased freshwater discharge as a result of spring runoff. The variations of isohaline positions in other months were not as pronounced. Vertical stratification was most pronounced in the lower and middle estuary on all cruises and generally decreased from the mouth to the head. Data collection in the upper estuary and freshwater zone (>25 km) was always performed while water was ebbing from the river, and the surface-to-bottom difference in density was always less than $2 \mathrm{~kg} \mathrm{~m}^{-3}$ at maximum stratification. Maximum vertical stratification occurred in May 1994 when the amount of freshwater runoff was at its peak in late spring. Salinity profiles at high tide, ebbing tide, low tide and flooding tide in September 1995 are shown in Fig. 3. The water column was stratified in the lower estuary throughout the tidal cycle while stratification in the middle and upper estuary occurred at ebbing tide and flooding tide but broke down at slack water during both high and low tides. In the freshwater zone, salinities were close to 0 and no vertical density gradient was detected.

\section{Chlorophyll a distributions}

The distributions of chl a are given in Figs. 4 \& 5 as longitudinal cross sections for each of the cruises. During winter (February 1994), chl a concentrations ranged from 0.8 to $1.1 \mu \mathrm{g} \mathrm{l}^{-1}$ in the only portion of the estuary that was free of ice and which could be sampled $(4.7$ to $21.1 \mathrm{~km}$ from the mouth). The distribution was more or less homogenous, with only slightly higher subsurface concentrations at the upstream station. In May 1994, the chl a concentrations peaked in the lower estuary at about $10 \mathrm{~km}$ from the mouth, with the highest value of $5.3 \mu \mathrm{g}$ $\mathrm{l}^{-1}$ at $5 \mathrm{~m}$ depth. The chl a concentrations were lowest in the middle portion of the estuary and then increased slightly farther upstream, resulting in a bimodal biomass distribution. This mid-estuary chl a minimum zone was observed again in June, July and September 1994, at about the same location (17 to $23 \mathrm{~km}$ from the mouth). In each case the chl a concentrations 
Fig. 4. Vertical section contour plots of phytoplankton chl $a$ along the length of the Kennebec estuary for each of 6 survey cruises, presented as depth versus distance in $\mathrm{km}$ from the mouth of the estuary. Depth of the $1 \%$ surface irradiance $(+)$ and critical depth $(\bullet)$ are given for each station sampled
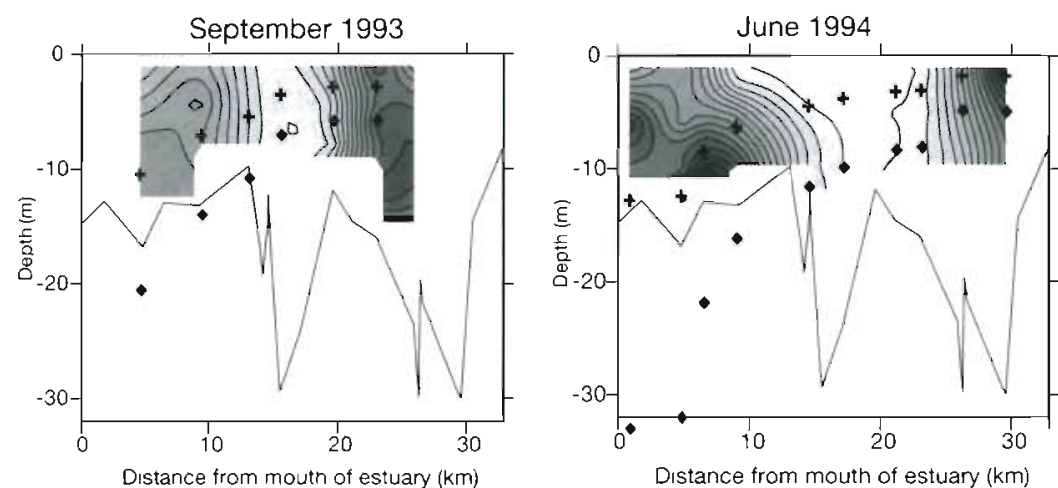

February 1994

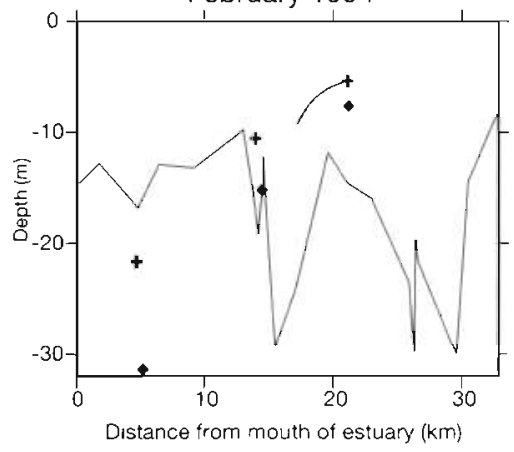

July 1994

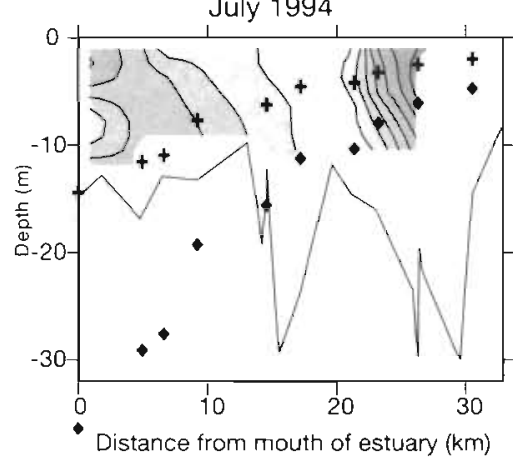

May 1994
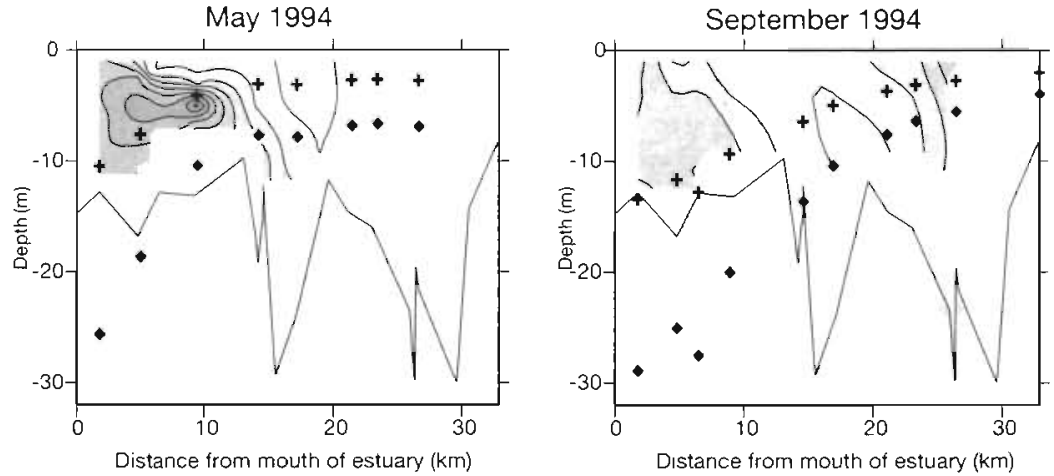

observed in June in the lower estuary $\left(10.2 \mu \mathrm{g} \mathrm{l}^{-1}\right)$. Concentrations at the mouth were low in summer $\left(2.8 \mathrm{\mu g}^{-1}\right.$ in

September 1994 and $3.9 \mu \mathrm{g} \mathrm{l}^{-1}$ in July 1994). In all surveys, the subsurface chl a values at the mouth of the estuary were greater than surface values, while the surface values at the head were similar to or greater than the subsurface values. It is possible that the low surface chl a at the mouth is a result of dilution by the phytoplankton-poor water from the middle estuary. The highest chl a concentrations in the upper estuary were measured at the uppermost station on each cruise and were generally greater than the highest values measured in the lower estuary.

In September 1993, a similar bimodal pattern of chl a distributions was observed but the location of the chl a minimum was closer to the lower estuary than in the other surveys. The chl a minima were found at salinities between 10 and 20 in those months that had prominent bimodal chl a patterns, i.e. September
1993, June, July and September 1994. In September 1995, chl a concentrations (Fig. 5) were measured from about $5 \mathrm{~km}$ from the mouth to the upper estuary, reaching the freshwater zone 4 times during a tidal cycle. The bimodal pattern of chl a distributions was observed again, with the minimum zone found between 10 and $20 \mathrm{~km}$ from the mouth. The position of the chlorophyll minimum shifted with the tide, from $10 \mathrm{~km}$ upstream of the mouth of the estuary at low tide to $20 \mathrm{~km}$ upstream at high tide (Fig. 5). In addition to mid-channel samples, chl a was also measured at the surface $(1 \mathrm{~m})$ on both sides of the channel, where bottom depths were less than the center channel. There were no significant differences between the channel values and those on the banks, indicating the water is laterally well mixed between the channel and the banks. 
High Tide

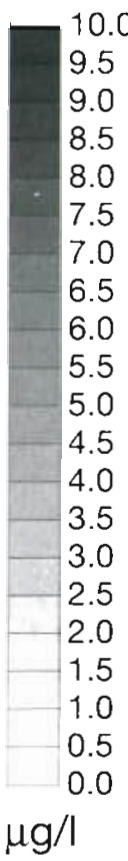

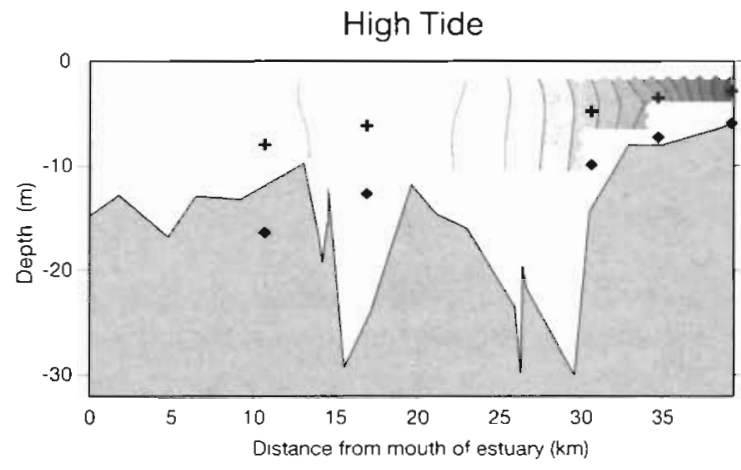

Ebbing Tide

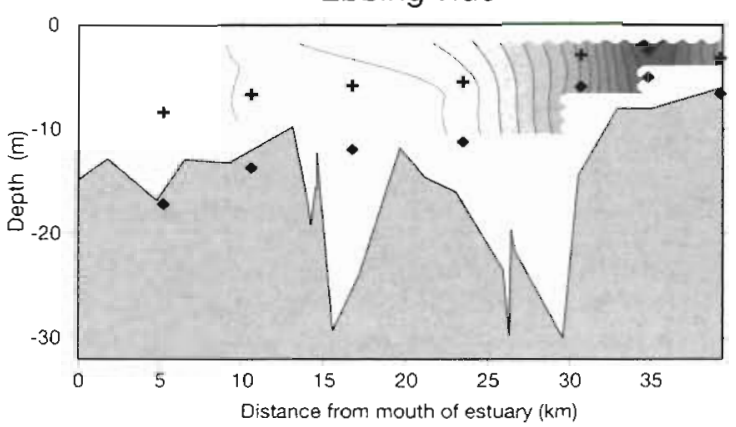

Low Tide

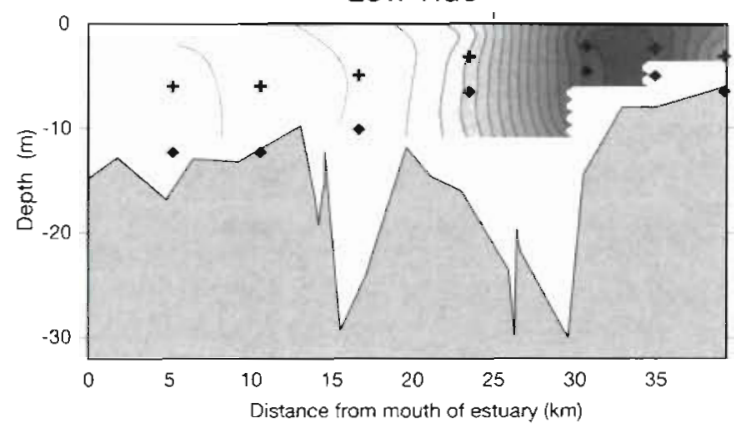

Flooding Tide

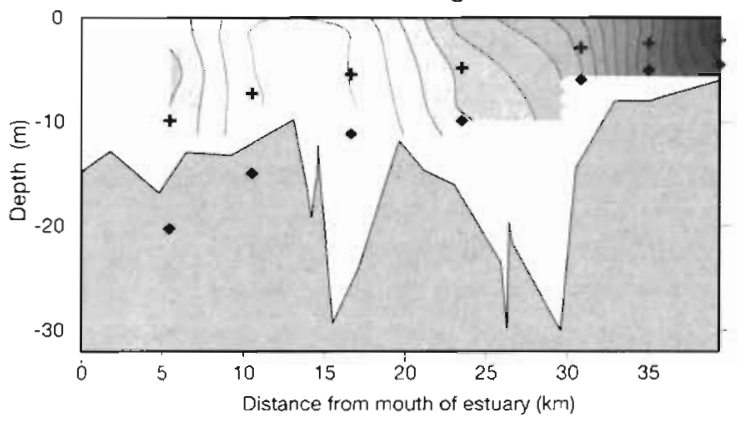

Fig. 5. Vertical section contour plots of phytoplankton chl a along the length of the Kennebec estuary for each of the tidal stages in the 16-17 September 1995 survey, presented as depth versus distance $(\mathrm{km})$ from the mouth of the estuary. Depth of the $1 \%$ surface irradiance $(+)$ and critical depth $(\bullet)$ are given for each station sampled

\section{Phytoplankton abundance and species composition}

Phytoplankton abundance (number of cells $\mathrm{ml}^{-1}$, or number of colonies/trichomes $\mathrm{ml}^{-1}$ ) showed a similar pattern to that of the bimodal chl a distributional patterns, supporting the assumption that chl a was an adequate indicator of phytoplankton abundance. However, the peaks were not directly proportional to one another because of individual differences in cell volume and chl a per cell among the dominant species. Throughout the whole estuary, diatoms were the most abundant group, with cyanobacteria following in second place although occurring only in the upper estuary. The lower estuary assemblage was mainly made up of coastal diatom species, including Skeletonema costatum (September 1993, 25.5\%; June 1994, 17.4\%; July 1994, 77.2\%; September 1994, 23.8\%), Chaetoceros sp. (September 1993, 26.0\%), Leptocylindrus minimus (September 1994, 24.6\%), Leptocylindrus danicus (May 1994, 13.7\%; September 1994, 10.9\%), Thalassiosira decipiens (May 1994, 32.9\%; June 1994, $10.4 \%$ ). Nitzschia delicatissima (June 1994, 43.5\%) and Eucampia zodiacus (September 1995, 3.9\%). In the upper estuary, the phytoplankton community was made up of diatoms, cyanobacteria (present in high abundance only in September of the 3 consecutive years) and green algae (Chlorophyceae). The major species in the upper estuary were Coscinodiscus rothii (February 1994, 11.2\%; September 1995, 8.9\%), Cyclotella sp. (September 1995, 25.2\%), Aulacoseira granulata (September 1993, 17.2\%; September 1994, $27.5 \%$; September 1995, 14.4\%), Asterionella formosa (February 1994, 21.0\%; May 1994, 14.9\%), Lyngbya nana (September 1995, 17.3\%), Oscillatoria acuminata (September 1995, 3.9\%) and Nodularia spumigena (September 1993, 13.7\%; September 1994, 3.9\%). Clumps of Polycystis sp. colonies were found floating on the surface and were clearly observable with the naked eye in the region around Twing Point on the September 1995 cruise. True benthic forms of diatoms were found only in very small numbers (Cymbella sp., Fragilaria sp., Gyrosigma sp., Navicula sp. and Synedra sp.). The filamentous cyanobacteria present in the Kennebec estuary were typical species of the intertidal zone, salt marsh and shallow water, apparently growing on bottom sediments and rocks as epiphytes (Humm \& Wicks 1980, Whitford \& Schumacher 1984), Dinoflagellates were present in very low abundance except in June and July 1994.

Three groups of phytoplankton were identified from the September 1995 survey (Table 1) using epifluorescence microscopy: Synechococcus sp. (coccoid Cyanobacteria), cryptophytes (Cryptophyceae) and chlorophytes (Chlorophyceae). These groups were not repre- 
Table 1. Cell density of major taxonomic groups determined by epifluorescence microscopy for September 1995

\begin{tabular}{|lccccccc|}
\hline & Dix Island & Phippsburg & Bluff Head & Fish Plant & Merrymeeting Bay & Twing Point Green Point \\
\hline Tide & Flooding & High & High & High & Low & Low & Low \\
Salinity & 29.32 & 26.63 & 20.22 & 11.53 & 1.72 & 0.24 & 0.07 \\
Depth (m) & 1.0 & 1.0 & 1.0 & 1.0 & 1.0 & 1.0 & - \\
Synechoccus sp. (no. ml- $l^{-1}$ ) & 19218 & 19163 & 11653 & 3900 & - & - \\
Cryptomonads (no. $l^{-1}$ ) & 1289 & 1049 & 1105 & 414 & - & - \\
Chloromonads (no. $l^{-1}$ ) & 1546 & 1160 & 3479 & 6523 & 10603 & 6406 & 9167 \\
\hline
\end{tabular}

sented in the settled samples reported for the other cruises primarily because of their small size, which ranged from 0.8 to $20 \mu \mathrm{m}$. Synechococcus sp. reached a density of $1.9 \times 10^{4}$ cells $\mathrm{ml}^{-1}$ at salinities between 27 and 29 and decreased to $1.2 \times 10^{4}$ cells ml $\mathrm{m}^{-1}$ at 20 . At a salinity of 11 , the density was $3.9 \times 10^{3}$ cells $\mathrm{ml}^{-1}$. The densities of cryptophytes were 1.0 to $1.3 \times 10^{3} \mathrm{cells} \mathrm{ml}^{-1}$ at the 3 stations in the lower estuary and $4.1 \times 10^{2}$ cells $\mathrm{ml}^{-1}$ further upstream at Fish Plant. In the upper estuary, where the salinity was between 0.07 and 1.72 , Synechococcus sp. and cryptophytes were not observed; they were either absent or masked by the great amounts of sediment and debris in the samples. The densities of chlorophytes increased gradually from the lower estuary toward the upper estuary, ranging from $1.2 \times 10^{3}$ to $1.1 \times 10^{4}$ cells $\mathrm{ml}^{-1}$. The densities of Synechococcus sp. in the Kennebec estuary are comparable to the densities reported for the Gulf of Maine, where they range from $10^{3}$ to $10^{4}$ cells $\mathrm{ml}^{-1}$ (Glover et al. 1985, Murphy \& Haugen 1985). Murphy \& Haugen (1985) also found that the numbers of photosynthetic eukaryotic cells were generally an order of magnitude lower than the numbers of cyanobacteria, which is also true in the Kennebec estuary.

The concentration of chl a and abundance of the major phytoplankton taxa are plotted in Fig. 6 as a function of salinity for the sampling surveys in September 1993, and May, June, July and September 1994. Chl a maxima were found at both the freshwater and seawater ends of the estuary, with the lowest values always being found at salinities between 10 and 20 . The species composition of the phytoplankton was correlated with salinity; for example, the coastal species Chaetoceros debilis, Skeletonema costatum and Thalassiosira decipiens were the 3 most abundant species at the mouth of the estuary, but declined in abundance with decreasing salinity toward the freshwater end. In September of 1993 and 1994, the densities of another group of species, made up of Aulacoseira granulata, a centric diatom, and Nodularia spumigena, a filamentous cyanobacterium, began to increase from the middle estuary to the upper estuary. The densities of green algae also increased in the upper estuary.

\section{Light attenuation}

On the first 6 cruises, the extinction coefficient, $k$, increased from $0.21 \mathrm{~m}^{-1}$ in the lower estuary to $2.41 \mathrm{~m}^{-1}$ in the upper estuary. Similar values at specific parts of the estuary were obtained throughout all the cruises except that of February 1994, during which the lowest $k$ values were found $\left(0.21\right.$ to $\left.0.87 \mathrm{~m}^{-1}\right)$. In September $1995, k$ varied from 0.5 to $2.0 \mathrm{~m}^{-1}$ and increased from the middle estuary to upper estuary.

The percentage of light attenuated by phytoplankton chlorophyll was calculated as

$$
\frac{k_{\text {chl a }}}{k_{\text {total }}} \times 100
$$

where $k_{\mathrm{ch} a}=\mathrm{chl}$ a concentration $\times 0.015 \mathrm{~m}^{-1}(\mu \mathrm{g} \mathrm{chl} \mathrm{a}$ $\left.\mathrm{l}^{-1}\right)^{-1}$ (Harding et al. 1986). The total extinction coefficient as well as the percentage of light attenuated by chl $a$ at all stations where data were available showed that phytoplankton standing stocks were responsible for less than $7.5 \%$ of the total $k$ at the turbid freshwater end of the Kennebec estuary, whereas in the clearest portion of the system (the seaward end) the corresponding values were as high as $27.2 \%$. The relative importance of phytoplankton in attenuating light was lowest in the middle estuary and corresponded with the chl a minimum zone just discussed.

The depths of $1 \%$ light, or the compensation depths $\left(z_{c}\right)$, were calculated as in Eq. (1), with the depth $z$ substituted by $z_{c}$,

$$
I_{z_{c}}=I_{0} \mathrm{e}^{-k z_{c}}
$$

Thus, the depth of $1 \%$ surface irradiance is:

$$
z_{\mathrm{c}}=\frac{-\ln (0.01)}{k}
$$

The computed compensation depths (1\% surface irradiance) are plotted in cross sections for the Kennebec estuary in Figs. 4 \& 5. More relevant to photosynthesis and primary production, however, is the critical depth (Sverdrup 1953). If we let $I_{z_{c}}$ be the compensation light intensity, and substitute it for $I_{z}$ in Eq. (1), we get Eq. (3) above. The depth at which the average light intensity in the overlying water column equals the compensation light intensity is the critical depth, $z_{\mathrm{CR}}$. This verti- 

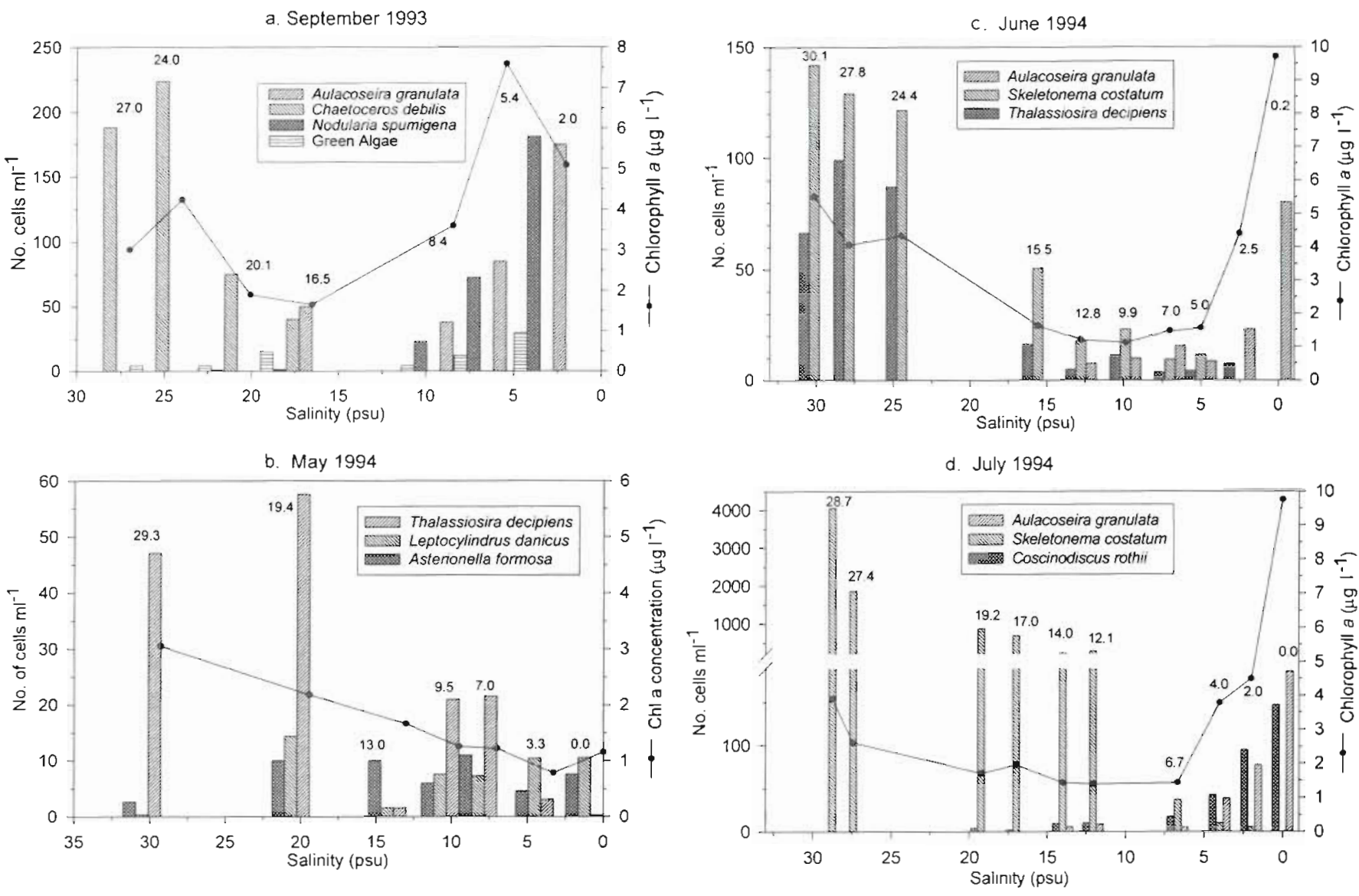

Fig. 6. Histogram plots of cell densities of the dominant phytoplankton taxa and plots of near-surface $(1 \mathrm{~m})$ phytoplankton chl a concentrations, each as a function of salinity. Actual salinity values are indicated for each sampling period. (a) September 1993; (b) May 1994; (c) June 1994; (d) July 1994; (e) September 1994

cally integrated compensation light intensity equal to $I_{z_{c}}$ can be calculated as:

$$
I_{z_{\mathrm{c}}}=\frac{I_{0}}{k z_{\mathrm{CR}}}\left(1-\mathrm{e}^{-k z_{\mathrm{CR}}}\right)
$$

If we assume this vertically integrated light intensity to be equal to an empirically determined critical light intensity, 40 ly d $\mathrm{d}^{-1}$ (Riley 1967. Townsend et al. 1994), the critical depth can be computed by knowing the incident light intensity and the extinction coefficient. This model assumes there is an even distribution and constant respiration of phytoplankton with depth, an excess of nutrients and that production is proportional to light. Grazing is implicitly included in the model although the grazers were not considered in this study. The incident light value received at the surface in the Kennebec estuary during the cruises and in the absence of cloud cover was calculated from the formula

$$
I_{0}=\alpha+\beta \sin (\omega \cdot t)
$$

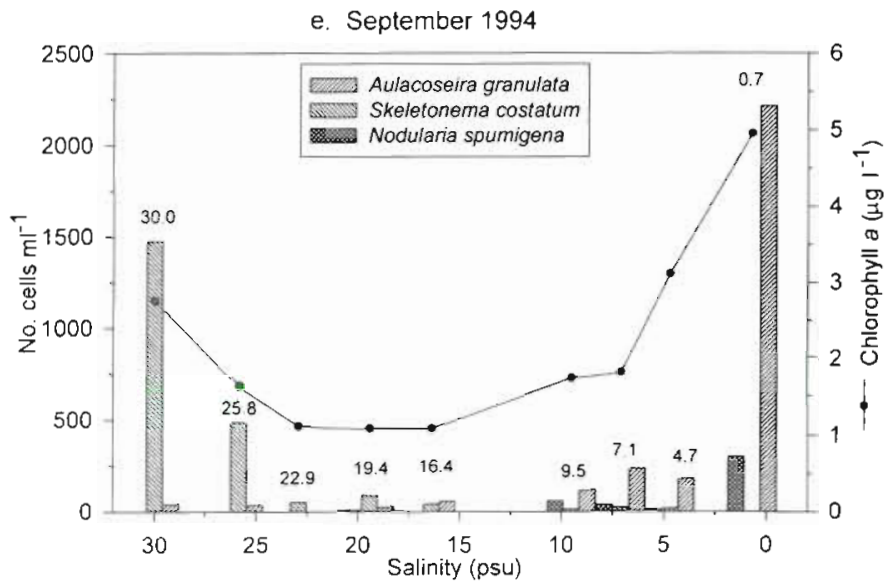

where $\alpha=$ the solar irradiance at the sea surface on the winter solstice; $\beta=$ the difference in solar irradiance at the sea surface between the winter and summer solstices; $\omega=\pi / 365$; and $t=$ day number after the winter solstice. Approximate values of $\alpha=124 \mathrm{ly} \mathrm{d}^{-1}$ and $\beta=$ 349 ly d ${ }^{-1}$ were used (Sverdrup et al. 1942). Using extinction coefficients calculated from measured in situ light intensities, the critical depth for each station was calculated and plotted on longitudinal sections of the estuary (Figs. $4 \& 5$ ). 
The critical depths in the lower estuary and half way to the middle estuary, about $15 \mathrm{~km}$ from the mouth, were deeper than or just touching the bottom for all the cruises. The critical depths became shallower toward the upper estuary and intersected the bottom at the point in the estuary where the chlorophyll minimum zone began, implying light limitation in that region. At 15 to $30 \mathrm{~km}$ from the mouth, critical depths were much shallower than the bottom depths (Figs. 4 \& 5), especially in regions where there are deep holes, where the bottom depth increases abruptly. Light appeared to be a limiting factor in the upper estuary as well, although, paradoxically, high chl a concentrations and cell densities were maintained there at least from May to September.

Critical depths at stations beyond $30 \mathrm{~km}$ from the mouth of the estuary in the September 1995 survey were shallower than the bottom depths, but those bottom depths are shallower than those in the middle part of the estuary farther downstream. The differences between the critical depths and bottom depths were less than $5 \mathrm{~m}$ in the upper estuary and the freshwater zone. However, during the ebbing and low tide, the critical depths were greater than the bottom depths at the uppermost station, Green Point, when the water from upstream was displaced farthest downstream. As a consequence, the entire upper estuary was light limited except at the uppermost station during low tide, when the clearer water from upstream enters the estuary.

\section{DISCUSSION}

The Kennebec estuary exhibits a wide range of temperatures and salinities, both seasonally and along its axis within seasons. The distributions of phytoplankton species tended to reflect the salinity distributions (Fig. 6) in keeping with reported preferences, e.g. Paasche (1975) and Brand (1984). This is similar to the general spatial distribution of phytoplankton in estuaries as discussed by Green (1968), who found that freshwater species dominate at salinities $<10$ and coastal species dominate at salinities $>20$, with the region between 10 and 20 being dominated by euglenoids, a group with low abundance in our study area. It was in this mid-estuary range of salinities that we observed the minimum in chl a concentrations and cell abundances. Salinity tolerances of true euryhaline species, such as Skeletonema costatum, an abundant species in our study, would not preclude them from growing in the mid-estuary where salinities ranged from 10 to 20 . Rather, it appeared that light availability in the middle region of the Kennebec estuary imparted a controlling influence on the optimal growth conditions.
Light is attenuated by scattering and absorption by dissolved and particulate materials. Suspended particulate materials (SPM), which primarily consist of sediments carried from the river and autochthonous particles produced in the upper estuary, are continually being diluted with seawater through mixing processes throughout the length of the estuary. This dilution, in addition to settling of particles, would be expected to result in increased water clarity toward the seawater end of the estuary. In the upper estuary at salinities $<5$, the amounts of autochthonous particles, as reflected by chl a concentrations and cell densities, were high and mainly composed of living phytoplankton cells, nonliving detritus (dead cells or fragments of cells) and aggregate particulates. Levels of SPM decreased gradually from the upper estuary to the lower estuary, as did the relative concentrations of dissolved organic matter (DOM) (Mayer et al. 1996). Thus, with high loads of SPM and DOM, phytoplankton in the upper estuary are more likely to experience light limitation than in the lower estuary, with cells in the middle estuary experiencing light environments somewhere in between. In September 1993, June 1994, and July 1994 and at stations that were $>30 \mathrm{~km}$ from the mouth in September 1995, our estimates of light attenuated by phytoplankton cells were high, exceeding $5 \%$ of the total, which Harding et al. (1986) considered as imposing a significant self-shading effect. Of course these characterizations of the light environment must be viewed in the context of vertical mixing.

The vertical density structure of the Kennebec estuary over a tidal cycle, as shown by the salinity distributions in Fig. 3, shows that from the middle to the lower estuary, short-term stratification and destratification events occur during a tidal cycle, indicating that the water column becomes unstable, and thus the depth of the mixed layer can be interpreted to extend to the bottom at those locations. Comparing the estimated critical depths and the bottom depths (Figs. $4 \& 5$ ) indicates that primary production in the lower estuary would not be expected to be limited by light, as the critical depths exceed the bottom depth. Thus, net production would be expected even if the water column were completely mixed from top to bottom. Proceeding from the middle estuary to the upper estuary, the critical depth at each station becomes shallower than the bottom depth, owing to increased light attenuation. Primary production would thus be light-limited in this region. Fig. 5 shows the critical depths with reference to the bottom depths in the upper Kennebec estuary and the changes during a tidal cycle in September 1995. The critical depths at the uppermost station (Green Point) were greater than the bottom depth during low and ebb tides and close to the bottom depth during high and flood tides. Thus, in this upper part of the estuary 
where river water enters the system (salinity at Green Point is 0.07 to 0.53 ), the phytoplankton populations were generally less limited by light, which would then explain the high chl a concentrations there (5.6 to $9.2 \mathrm{\mu g} \mathrm{l}^{-1}$ at the center of the channel). However, at the next station. Twing Point, which is located about $4.5 \mathrm{~km}$ downstream, chl a concentrations were as high as 5.1 to $8.6 \mu \mathrm{g} \mathrm{l}^{-1}$ despite the critical depths being shallower than the bottom depth; cells sampled here were likely delivered from upstream. Continuing down the estuary to the next station, Merrymeeting Bay, chl a concentrations showed the greatest fluctuation over the tidal cycle, ranging from 2.9 to $8.1 \mathrm{\mu g} \mathrm{l}^{-1}$. As was the case at Twing Point just upstream, the critical depth at Merrymeeting Bay was shallower than the bottom depth. So from Twing Point downstream the phytoplankton growth started to become limited by light.

A possible explanation for the high chl a concentrations in portions of the upper estuary, despite light limitation, is the transport of phytoplankton biomass into the area from the extensive areas of shallow marshlands (ca $1 \mathrm{~m}$ depth) in the upper part of the Kennebec estuary (Fig. 1). Upstream of Merrymeeting Bay the channel is bounded by marshes and a side channel with depths less than $3 \mathrm{~m}$ joining the main channel between Twing Point and Green Point; the central channel is 1 to $3 \mathrm{~m}$ deep. Those shallow areas were not sampled because of inaccessibility by the research vessel. The phytoplankton species assemblage collected at the upstream channel included epiphytic or tychoplanktonic species (filamentous cyanobacteria) which were among the major species present at the Twing Point and Merrymeeting Bay stations, suggesting that phytoplankton cells were being washed into the river from the shallows. Highest productivity in such systems is usually found in benthic communities (Kirk 1994). If the tidal movement or wind forcing is strong enough to resuspend the epiphytic phytoplankton, the large areas of shallow depths around the channel might be able to supply the high chl a concentrations and high cell counts seen in the channel of the upper estuary under conditions that would ordinarily be light limiting.

The result of these patterns of light limitation, salinity preferences, and freshwater sources of cells is a bimodal distribution of phytoplankton biomass, being lower in the middle reaches of the estuary than further north nearer the freshwater zone or further downstream in the lower estuary (Figs, 4 \& 5). The chl a minimum zone coincided with that part of the estuary where the critical depth intersected the bottom, reflecting a transition to light-limited conditions. If we assume that as the freshwater enters the estuary the growth of phytoplankton becomes light limited, fol- lowed by cell death by grazing and subsequent decomposition of that organic material as it is advected downstream, we would expect to see a concomitant increase in the relative importance of the degraded forms of chlorophyll (phaeopigments). The observed changes in chl $a$ and phaeopigments with salinity on the September 1995 cruise would support such a contention (Fig. 7). The ratios of phaeopigments to chl a increased from the uppermost station (0.24 to 0.67) downstream and were greatest $(>1)$ in the salinity range of 5 to 20 , suggesting that phytoplankton cells were in good physiological condition at the time they entered the system at the freshwater zone, and that they subsequently died or were eaten and partially digested by grazers and started to be decomposed in the particle maximum region. The ratio decreased again in the lower estuary where the chl a concentrations began to increase slightly. As the chl a concentrations decreased from the freshwater zone toward the middle estuary, the ratios of phaeopigments to $\mathrm{chl}$ a remained high, and cell densities were always low in this middle region, in agreement with low chl a concentrations.

The distributions of inorganic nutrients in the Kennebec during this study, reported by Schoudel (1996), also provide support for this interpretation. Schoudel's (1996) data showed that nutrients may have been limiting during July and August, and possibly September, but, interestingly, his nutrient versus salinity relationships showed that lowest concentrations $(<1 \mu \mathrm{M})$ of nitrate + nitrite, and especially ammonium, were at either end of the estuary. The mid-region in the estuary, coincident with the chlorophyll minima, exhibited elevated nitrogenous nutrient concentrations in summer (2 to $3 \mu \mathrm{M}$ greater than end-member concentrations), perhaps in relation to local nitrification processes as materials produced at either end of the estuary were decomposed and transported toward the mid-region.

In summary, these results demonstrate that the Kennebec estuary is a dynamic system, which exhibits a wide range of phytoplankton species composition and abundance, which in turn can be related to the effects on phytoplankton of salinity preferences and light limitation. The overall biological productivity of the estuary would appear to be less than expected, in that it is limited by a combination of factors, including its geographical length. That is, the length of the Kennebec estuary relative to advective flows and growth rates of phytoplankton results in a longitudinal progression of identifiable phytoplankton growth environments, beginning at both the seaward and freshwater ends. Freshwater phytoplankton at the head of the estuary, which apparently grow well in the shallow-water marshes and river banks there, become light limited 


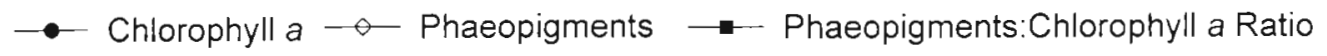

Fig. 7. Plots of near-surface phytoplankton chl a and pheopigments, and the ratio of phaeopigments to chl $a_{\text {, for each of }}$ the 4 tidal stages sampled during the 16-17 September 1995 survey
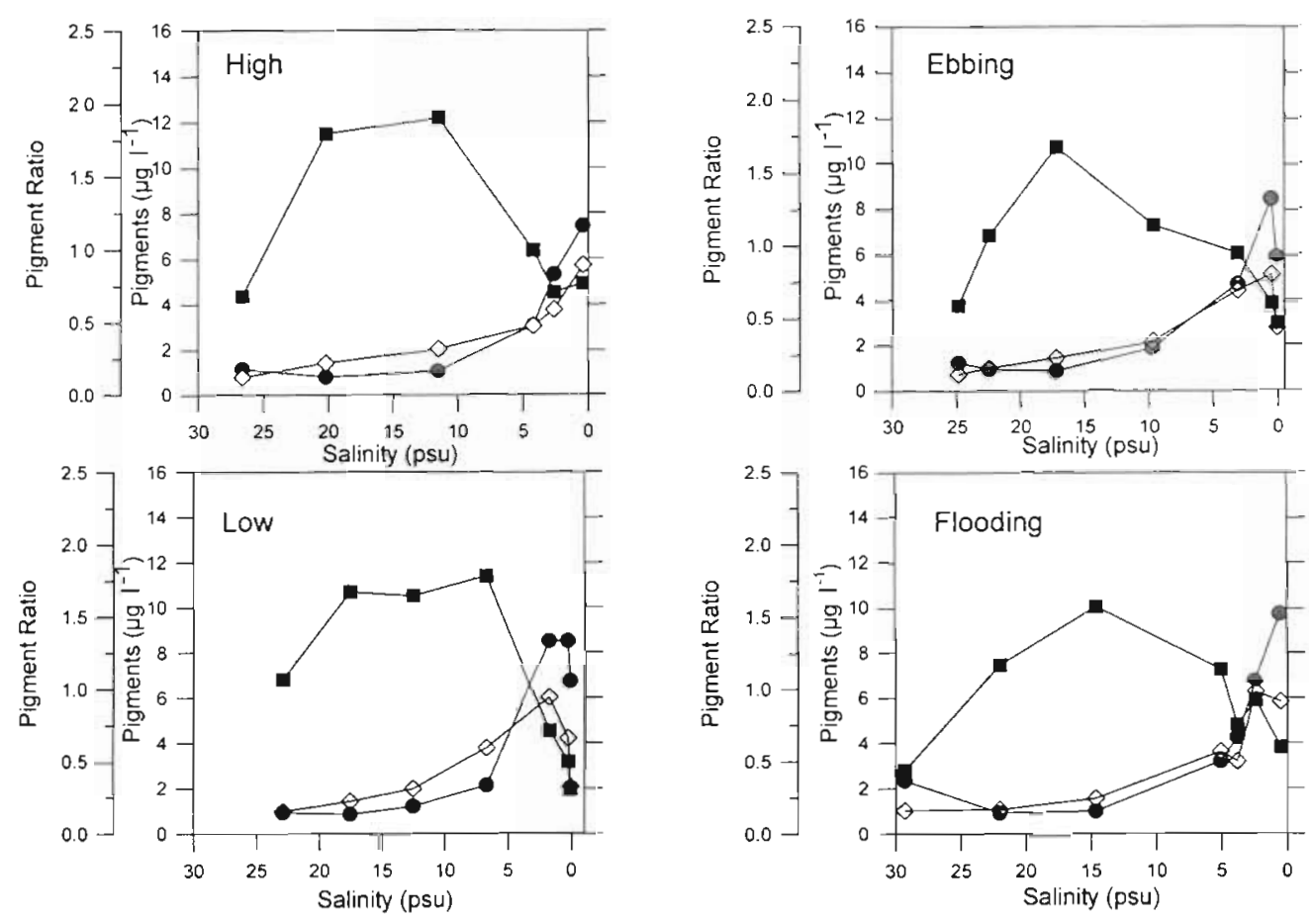

LITERATURE CITED

upon initial introduction into the system. Thus, chlorophyll levels at the head are relatively high. As those waters flow seaward, and the organic matter decomposes, nutrients are regenerated, producing a midestuary peak in dissolved inorganic nitrogenous nutrients (Schoudel 1996). Continuing seaward, phytoplankton are no longer light limited, and, in the presence of regenerated nutrients and new nutrients delivered from coastal waters, phytoplankton biomass increases. The pattern that emerges is a bimodal biomass distribution of phytoplankton, with the midregion comprising a low productivity area of organic matter recycling and nutrient regeneration.

Acknowledgements. We thank our colleagues at the University of Maine (L. Mayer, N. Pettigrew, D. Kistner Morris, J. Wallinga, and A. Laursen), the Bigelow Laboratory (J. Brown and $M$. Sieracki), and the University of New Hampshire (T. Loder, D. Schoudel, and K. Coniaris) for their assistance at sea and in the laboratory and for many valuable discussions. We gratefully acknowledge the capable assistance of the captain and crew of the RV 'Gulf Challenger' Finally, we extend special thanks to Dr Bernie McAlice of the University of Maine, who provided valuable insights and advice prior to, and throughout, this study, and who was always cheerfully available to identify virtually any planktonic organisms we placed before him. This work was supported by a grant from the Maine-New Hampshire Sea Grant Program of NOAA.
Apollonio S (1979) The Gulf of Maine. Courier-Gazzette, Inc, Rockland, ME

Brand LE (1984) The salinity tolerance of forty-six marine phytoplankton isolates. Estuar Coast Shelf Sci 18(5): 543-556

Francis JRD, Stommel H, Farmer HG, Parsons D Jr (1953) Observations of turbulent mixing processes in a tidal estuary. Woods Hole Oceanographic Institution Ref No. 53-22

Glover HE, Phinney DA, Yentsch CS (1985) Photosynthetic characteristics of picoplankton compared with those of larger populations, in various water masses in the Gulf of Maine. Biol Oceanogr 3:223-248.

Green J (1968) The biology of estuarine animals. Sidgwick \& Jackson, London

Harding LW, Meeson BW Jr, Fisher TR Jr (1986) Phytoplankton production in two east coast estuaries: photosynthesislight functions and patterns of carbon assimilation in Chesapeake and Delaware Bays. Estuar Coast Shelf Sci 23:773-806

Humm HJ, Wicks SR (1980) Introduction and guide to the marine bluegreen algae. John Wiley and Sons, New York

Kirk JTO (1994) Light and photosynthesis in aquatic ecosystems, 2nd edn. Cambridge University Press, Cambridge

Laursen AK, Mayer LM, Townsend DW (1996) Lability of proteinaceous material in estuarine seston and subcellular fractions of phytoplankton. Mar Ecol Prog Ser 136: 227-234

Mayer LM, Townsend DW, Pettigrew NR, Loder TC, Wong MW, Kistner-Morris D, Laursen AK, Schoudel AD, Coniaris C, Brown J, Newell C (1996) The Kennebec, Sheepscot and Damariscotta estuaries: seasonal oceanographic data. Univ Maine Dept Oceanography Tech Rep 
No. 9601, Maine Sea Grant Tech Rep 96-01

Murphy LS, Haugen EM (1985) The distribution and abundance of phototrophic ultraplankton in the North Atlantic. Limnol Oceanogr 30: 47-58

Paasche $E$ (1975) The influence of salinity on the growth of some plankton diatoms from brackish water. Norw J Bot 22:209-215

Parsons TR, Maita Y, Lalli C 1 (1984) A manual of chemical and biological methods for seawater analysis. Pergamon Press, Oxford

Riley GA (1967) The plankton of estuaries. In: Lauff GH (ed) Estuaries. American Association for the Advancement of Science Publication 83, Washington, DC, p $316-326$

Schoudel D (1996) The seasonal variation of nutrients in three Maine estuaries. MS thesis, Univ New Hampshire

Sieracki ME, Verity PG, Stoecker DK (1993) Plankton com-

Editorial responsibility: Kenneth Sherman (Contributing

Editor), Narragansett, Rhode Island, USA munity response to sequential silicate and nitrate depletion during the 1989 North Atlantic spring bloom. DeepSea Res ll 40(1/2):213-225

Strickland JDH, Parsons TR (1972) A practical handbook of seawater analysis. Bull Fish Res Board Can 167

Sverdrup HU (1953) On conditions for the vernal blooming of phytoplankton. J Cons 18:287-295

Sverdrup HU, Johnson MW. Fleming RH (1942) The oceans: their physics, chemistry and general biology. PrenticeHall, Englewood Cliffs, N.J

Townsend DW, Cammen LM, Holligan PM, Campbell DE, Pettigrew NR (1994) Causes and consequences of variability in the timing of spring phytoplankton blooms. DeepSea Res I 41(5/6):747-765

Whitford LA, Schumacher GJ (1984) A manual of fresh-water algae. Sparks Press, Raleigh, NC

Submitted: March 15, 1998; Accepted: October 26, 1998 Proofs received from author(s): February 18, 1999 